\title{
INTERNAL COMMUNICATION AND ITS IMPACT ON MANAGEMENT ON THE EXAMPLE OF THE TERRITORIAL GOVERNMENT UNIT
}

\author{
Barbara Kielbasa ${ }^{1}, \mathrm{PhD}$; Agnieszka Werenowska ${ }^{2}, \mathrm{PhD}$; and Karolina Cwiertnia ${ }^{3}$, bachelor \\ ${ }_{1,3}$ University of Agriculture in Krakow, Poland, ${ }^{2}$ Warsaw University of Life Sciences - SGGW
}

\begin{abstract}
The article presents the importance of communication processes in territorial government units to increase the quality of management with both knowledge and information. The theoretical part presents the essence of internal communication and the principles of new public management. In the empirical part, an analysis of the results of surveys conducted among officials working in the District Office in Busko-Zdroj, Swietokrzyskie Voivodship (south-eastern Poland) was carried out. The article uses a descriptive method, the data are presented in a tabular format. According to the analyses carried out, the biggest problem indicated by respondents was the lack of operational efficiency of information as well as poor use of modern instruments such as intranet, business mobile phones or videoconferencing. The conducted research indicated the need to create integrated networks in order to improve flow of information processes as well as to introduce a new form of learning (exchange of knowledge and information) in teams.
\end{abstract}

Key words: internal communication, territorial government, new public management.

JEL code: $M 1, \mathrm{H} 8$.

\section{Introduction}

Communication in every organization is indicated as a key factor for organization development (Kantane I., Sloka B., Vilcina A., Ozolina I., 2012). Communication processes are one of the determinants of the quality of the organization's management, they determine the effectiveness and efficiency of management to a large extent (Kielbasa B., Kalinowski S., 2018). Communication in each organization affects directly the implementation of basic management functions, i.e. planning, organizing, motivating and controlling.

The influence of communication processes on the management of territorial government units is similar, despite the fact that they implement other goals, including non-financial, public, social ones (Prus P., Drzazdzynska K., 2017). Rules for the functioning of territorial government units are determined by the European Charter of Local Self-government. It states that "local self-government is the right and ability of the local community to manage and control a fundamental part of public affairs on their own responsibility and in the interests of their residents" (European Charter of Local Self-Government, 2013). Thus, the territorial self-government is a public entity which covers all inhabitants of a given area (Act of 5 June 1998 on district self-government, Journal of Laws of 2018, item 995).

The aim of the study is to analyse the importance of internal communication processes for the quality of knowledge and information management on the example of a local government unit as well as identification of barriers for internal communication processes and the possibility of their elimination. The research is qualitative and refers to the case study of a selected unit. The subject matter is the office and headquarters of the Starost ${ }^{4}$ and administrative authorities of the district. The study covered officials working in the Starost District Office in Busko-Zdroj, Swietokrzyskie Voivodship (south-eastern part of Poland). A survey method with a questionnaire of standardized questions was used to obtain primary data. The questionnaire contained 10 questions (including cafeteria and open questions). The article discusses the problem of the quality of internal

\footnotetext{
${ }^{1}$ Corresponding author. E-mail address: bkielbasa@ar.krakow.pl

2 E-mail address: agnieszka_werenowska@sggw.pl

3 E-mail address: karo16.955@o2.pl

4 Starost District Office is an auxiliary unit appointed for the purpose of executing orders of the district management, president of the management

and resolutions of the district council. Encyclopedia of management, Retrived: https://mfiles.pl/pl/index.php/Starostwo_powiatowe, Access:

10.01.2019
} 
communication which significantly affects the effectiveness of communication with the external environment.

\section{The essence and importance of internal communication in public units}

Internal communication in organizational units is one of the most important element of human resources management. Both public and non-public units must equally care for the quality of communication. In public units these processes run in a similar way as in other organizations but their nature and purpose are slightly different. In the paper of Z. Kruzmetra, B. Bite and G. Kronberga (2018), they emphasize "the responsibility of local governments to build communication with people, to develop safe and sustainable communities, to provide services, build trust and reduce social distances". It should be remembered that communication with the environment in self-government units is public. It is formal, takes place in a specific communication space and is aimed at transferring and exchanging information of public use and maintaining social ties (Smalec A., 2015; Marcysiak T., Prus P., 2017). This type of communication is limited to the public and formal sphere, i.e. to a territory regulated by law. Thus, the communication context, that is the conditions of the local public space in which communication processes occur, should be taken into account in communication processes with the environment (Figure 1).

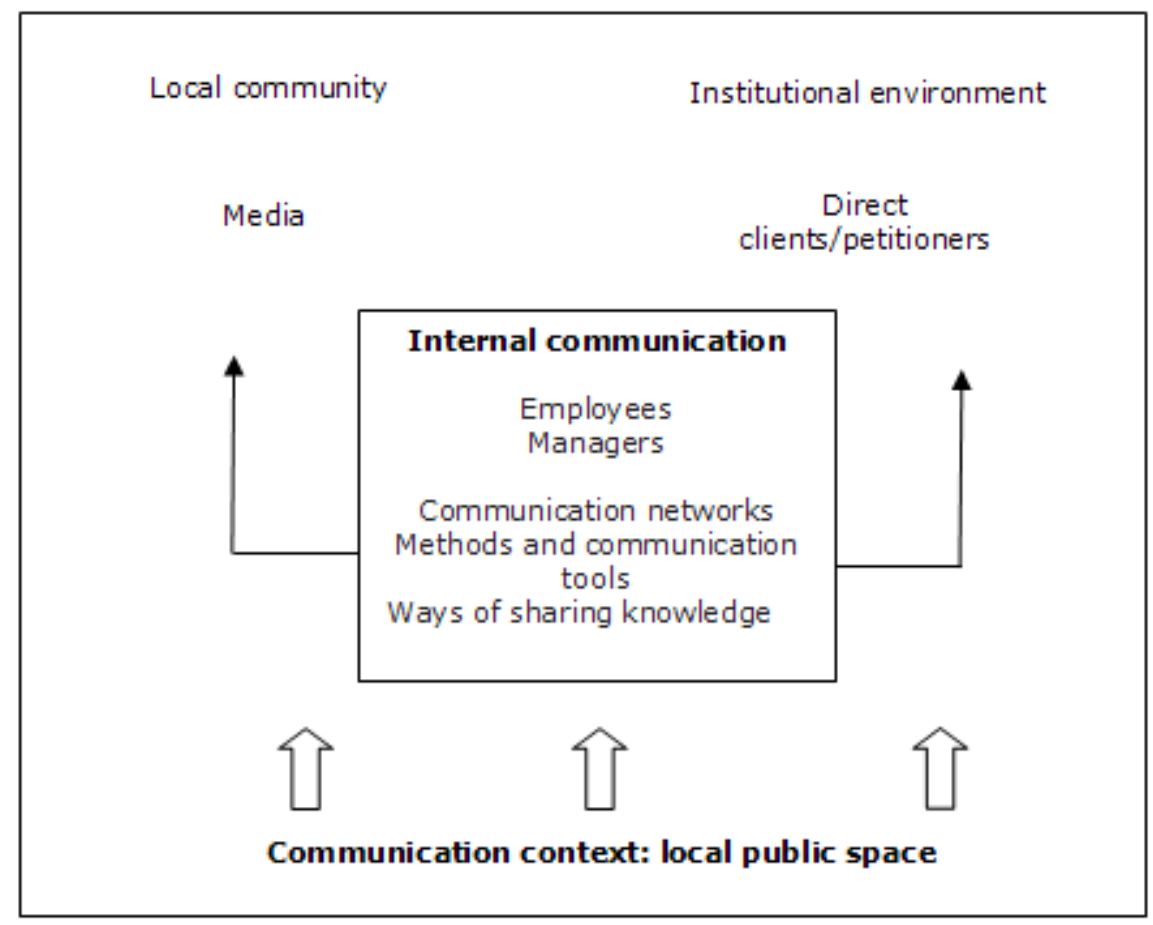

Source: authors' construction

Fig. 1. Main elements of a communication process on the example of a territorial government unit

External communication is the relationship of the organization with the environment, in this case with the inhabitants of the commune, representatives of the authorities of other units, local media, etc. (Figure 1). The most important thing in every local government unit is communication with citizens. Characterizing the processes of communication with the environment (external communication) it should be noted that it is primarily informative. The flow of information to the public communication system is usually planned, routine and complies with the procedures established by law. Public communication deals primarily with the management of public data and the regulation of relations between public services and its users (Poznanska A., 2012). It also includes 
providing the media with information, organizing press conferences, giving interviews, providing promotional and informational materials, international cooperation, conducting electronic correspondence, writing reports and materials. Generally, these are all activities that aim to represent the organization outside and provide the environment with information (Figure 1).

Internal communication is of particular interest in this article. It affects the quality of relationships with the environment and can improve it. In the absence of effective communication within the organization external communication will also be difficult. Internal communication refers to the relationship between employees of the unit, managers and management. It takes place in various networks and working teams (command or task) (Ober J., 2007). It is important to create appropriate teams and communication networks that influence the activity and motivation of employees and also allow them to identify themselves with the organization. This contributes, to a large extent, to achieving the assumed goals, creating an organizational culture, and also promotes organizational learning (Killigsworth C., 2009).

Internal communication is operational, hence the "operativeness" of communication (information, knowledge, messages) in the process of performing current tasks is important (Mistre Z., Zvaigzne A., 2012). In achieving operational goals it is necessary to achieve effective (Drucker P., 2006):

- informative communication (involving the transfer of data, information and knowledge), and

- persuasive communication (allows to motivate and encourage employees to carry out assigned tasks).

Communication barriers inside the organization make it difficult to design effective strategic messages that are extremely important in managing local development (Nielsen J. A., Salomonsen Houlberg H., 2012). Therefore, it is possible to put forward the thesis that the more effective internal communication is, the more effective the processes of communication with the environment will be.

\section{New Public Management (NPM) as an indicator of internal communication in public units}

Internal communication area in organizations faces ever newer challenges. Developing digitization processes are the basis for changes taking place in a very important process of internal communication, which must keep up with modern trends and the needs of its recipients. The analysis of the results of research conducted in 2016 by GFMP Management Consultants "The future of internal communication" (Internal Communication, GFMP Report, 2016) showed that as many as $62 \%$ of the surveyed communication staff say that it is much easier to get with information to employees today. In contrast, they saw the communication barrier on the side of management and the attitudes of employees themselves.

The idea of new public management is to replace the bureaucratic model of administrative management with a managerial model. It comes down to applying in the public sector principles and management models used in the private sector. According to J. Supernat (2004), this model points out: introducing market mechanisms, focusing on the client, creating appropriate conditions encouraging employees to take initiatives, drawing attention to innovation and enterprise. Internal communication is one of the important elements.

In the aforementioned report, where 11 sectors were surveyed, including administration, offices and NGO - $61 \%$ of these organizations had a formally developed internal communication strategy and more than half of them checked communication efficiency, of which $30 \%$ on a regular basis and 
$46 \%$ irregularly (Internal Communication, GFMP Report, 2016). This very important issue requires constant evaluation and raising of standards. Communication at the highest level means not only an efficient circulation of information, improving the quality of services but also a quick reaction in crisis situations and creating a positive image of a public entity (Cutlip S. M., Center A. H., Broom G. M., 2006).

The values of New Public Management are so-called Three "E": Effectiveness, Efficiency and Economy (Shaping the Communication Process ..., 2014). The implementation of these values by public units is No longer a fashion but a necessity in the $21^{\text {st }}$ century. Conducting organizational transformations, creating new procedures or motivation systems is necessary for increasing the competitiveness of offices and satisfying the needs of stakeholders.

Internal communication is a basic element of creating an organizational culture. It is a kind of dialogue between all levels of structures in the organization. Efficient internal communication as well as loyal and well-informed employees are the strength of every unit, becoming more flexible and willing to react quickly in any situation, especially crisis situations. The saying „public relations starts at home ... (means inside)" especially emphasizes the role of internal communication and creating positive internal relations that have a direct impact on external communication processes (Maruszak P., 2014). In the case of offices these relations are the essence of creating a positive image in the group of stakeholders.

As the results of surveys conducted in 2017 by Emplo company supporting communication in organizations show, there are still many problems in the communication processes with which employees have to struggle on a daily basis. It turns out that as many as every fourth employee of medium and large enterprises in Poland has a sense of uninformed about the activities carried out by their employer and $71 \%$ think that the organization will not succeed in business without partner and open communication with employees. According to employees, department managers should be primarily responsible for an efficient flow of information (67\% of responses) (Business Efficiency ..., 2017).

\section{Research results and discussion}

In total, 106 employees were employed in the analysed Starost District Office. As a result of the research carried out in 2018, there were answers from 63 officials from various levels of the organizational structure (trainees, specialists, department heads). The sample included 44 women and 19 men aged 20-64. People aged 36-50 (44\%) dominated in the sample. More experienced people: aged 51-60 were quite a large group (25\%). The sample also included people with lower professional experience: aged 20-35 (24\%). The analysed institution also employed people in preretirement age (61-64 years) - in the sample they were 4 people. Based on the analysis of the demographic structure of employed officials it can be noted that the surveyed organization is characterized by a relatively young staff with extensive professional experience and an advantage of female employees.

Table 1 presents the aggregated answers of respondents to the use of different communication networks to carry out assigned tasks or solve problems. Respondents indicated the networks most frequently used in the organization and then assessed their effectiveness in solving problems or achieving goals - on a scale of 1 to 5 , where 5 meant the best and 1 the lowest grade. 


\section{Application and assessment of the effectiveness of popular types of communication networks in the institution under study, in the opinion of respondents}

\begin{tabular}{|l|c|c|c|}
\hline No & $\begin{array}{c}\text { The type of } \\
\text { communication } \\
\text { networks }\end{array}$ & $\begin{array}{c}\text { Application } \\
\text { (rating from 5 to 1, where 5 is } \\
\text { the most used type and 1 is the } \\
\text { least frequently used) }\end{array}$ & $\begin{array}{c}\text { Effectiveness } \\
\text { (rating from 5 to 1, where 5 is } \\
\text { the most effective type and 1 is } \\
\text { ineffective) }\end{array}$ \\
\hline $\mathbf{1 .}$ & Chain type network & 2.5 & 4.0 \\
\hline $\mathbf{2 .}$ & Circular network & 3.0 & 3.0 \\
\hline $\mathbf{3 .}$ & Star type network & 3.0 & 3.0 \\
\hline $\mathbf{4}$ & Integrated network & 1.5 & 4.0 \\
\hline
\end{tabular}

Source: authors' research

The most frequently used network was the circular and "star" type one, due to the fact that employees operate within departments on a daily basis - working in command teams and cooperating in strictly defined teams (i.e. a specific department). In such a network each post has the same position in relation to the others and there is a possibility of direct communication with employees in a given department. At the head of each department there is a manager - a person occupying a central position in relation to all the others (a "star" type network). Thanks to this, there is a possibility of fast, direct and two-way communication and monitoring of its course. A "chain" type network is also used quite often in the surveyed Starost Office (Table 1). It is used to carry out every day, routine tasks as well as those that are divided into smaller elements. As for assessing the effectiveness of communication networks to solve problems and achieve the organization goals - the most-rated was integrated network (peer-to-peer). It allows employees to communicate freely and there is No person in a dominant position (manager, director). This type of cooperation was not frequently used in the organization under study (Table 1). Integrated networks are created to perform difficult and complex tasks that require an interdisciplinary approach (e.g. project management). A valuable example of such projects can be investments implemented from funds obtained from EU which require consistent cooperation and exchange of information between employees of various cells and organizational levels (Satola L., 2014). Apart from the integrated network, the employees rated the "chain" type of network very highly due to the implementation of procedural and routine tasks resulting from the specificity of work in a public unit of this type.

The analysis of the results of the survey clearly indicated the diversification of the assessment of internal communication processes in the surveyed organization. These processes were positively rated by 31 respondents and negatively by 32. This may indicate a lack of coherence in the management of internal communication processes and points the existence of conscious communication barriers. The respondents indicated the most important barriers that in their opinion generate problems in the processes of internal communication, also implicating - to a large extent the quality of communication with the environment. Figure 2 presents the barriers indicated by 32 employees of the analysed institution who made a negative assessment of internal communication processes. Respondents could point to several communication barriers occurring in the organization under study. 


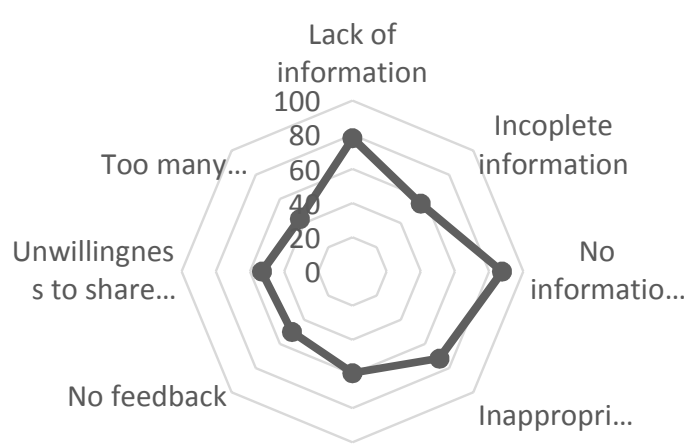

No contact...

\section{Source: authors' research}

Fig. 2. Barriers to internal communication, in the opinion of the respondents $(n=32)$

Identified barriers can be divided into organizational and individual ones. Some of them penetrate each other, affecting each other which is why they are difficult to separate. The biggest problem indicated by the respondents was the lack of information operability i.e. the lack of information when it is necessary for the implementation of the assigned tasks. It often arrives too late. This problem was indicated by $3 / 4$ of respondents (Figure 2). A significant group of almost $80 \%$ of respondents pointed to a very serious problem of the lack of information. The reason for this is the cost of acquiring knowledge and information, often too high for a small public unit. The reason may also be the lack of awareness of sources of knowledge and information (employees or managers do not know where to look for information). An important problem according to the respondents was also the inadequate form of the message, e.g. an illegible, incomprehensible message, incompatible with the software used etc. According to some respondents, the lack of contact with the immediate supervisor generates significant communication problems. According to them, the lack of meetings or conversations with the manager or the management block two-way communication and makes the information that reaches employees not "first hand" information. It also involves the lack of feedback and incentives to share knowledge and information in employee teams. Respondents also stressed the need to reduce the level of formalization of communication processes (including those in writing) and to enable and encourage informal contacts - in interpersonal-direct form (direct conversation). This type of communication contributes to building an organizational culture and is an effective way to exchange knowledge and information between employees.

Internal communication in the organization uses various tools and instruments. These tools work in different ways, have their advantages and disadvantages. The variety of instruments allows employees to adapt better to the situation and provides them with an ability to prepare effective messages and choose an appropriate communication channel. In the surveyed public unit, almost $33 \%$ of employees participating in the study recognized direct contacts (interpersonal-direct communication) as the basic way of communication with colleagues. In the second place, telephone calls were indicated ( $26 \%$ ) as a form of interpersonal communication using the medium (telephone device). For almost $24 \%$ of respondents, meetings and conferences (group communication) are important. The Internet has become the main tool for communication and collecting of information in many organizations (Werenowska A., 2014), the respondents also saw this instrument. They indicated e-mail as an effective way of transferring and receiving information (17\%). 
When analysing the information obtained from the employees of the public unit under study regarding the need to implement new internal communication tools, a few were pointed out:

- Internal internet forum (Intranet) - $38.1 \%$ of responses;

- Business mobile telephones - $31.1 \%$;

- Videoconferencing - 25.4\%;

- Electronic information boards - $5.4 \%$.

The medium that allows the fastest information transfer is undoubtedly the Internet and this particular means of communication has clearly inspired changes in the style of media use in recent years. Information has become the main attribute of information society and it has developed as a result of the use of new information and communication technologies (ICT) (Jaska E., Werenowska A., 2018). It is worth using this potential in improving internal communication of the analysed unit.

\section{Conclusions}

1) A new approach to the management of public entities indicates the de-bureaucracy of the internal communication system in this type of units and the introduction of a managerial model. This need was also noted by the employees of the surveyed organization who evaluated the communication system and pointed to the needs in this area. They highly appreciated the importance of direct communication in the performance of their duties. Despite the large acceptance of this form of communication, they drew attention to the need for intensive use of modern instruments such as intranet, business mobile telephones or videoconferences. Their combination with traditional instruments and the creation of a two-way communication system can be the basis for improving the communication system in public units.

2) For the efficiency of communication systems in an organization, the knowledge about barriers to these processes and ways to eliminate them is necessary. The conducted research allowed to distinguish organizational barriers as well as those of an individual character. The biggest problem indicated by the respondents was the lack of information operability i.e. the lack of information when it is necessary to carry out the assigned tasks. There is an informational gap. In order to prevent this, new tools should be introduced to obtain information when it is needed to carry out task or additional resources should be obtained, thanks to which it will be possible to purchase knowledge and information in a timely manner.

3) In the surveyed unit the need to create integrated networks in order to improve the exchange of knowledge and information and learning in teams was also indicated. The implementation of routine tasks does not allow the full use of the employees' capabilities and does not ensure effective information exchange within the organization. The creation of integrated networks and the implementation of tasks in the form of a project can change the social perception of local government units, thanks to the increased effectiveness of internal communication.

\section{Bibliography}

1. Cutlip, S.M., Center, A.H, Broom, G.M. (2006) Effective Public Relations. 9th ed. Upper Saddle River. NJ: Prentice-Hall. pp. 212-218.

2. Drucker, P. (2006) The Practice of Management. HarperBusiness. pp. 218-234.

3. Efektywnosc biznesowa zaczyna się od komunikacji wewnetrznej (Business Efficiency Begins With Internal Communication), Badanie Emplo (Emplo Research), 2017, Retrieved: https://emplo.com/ebook/przewodnik-o-komunikacji-dla-managera-pl/\#lp-code-347, Access: 7.01.2019.

4. Encyklopedia Zarzadzania (Encyclopedia of Management), Retrieved: https://mfiles.pl/pl/index.php/Starostwo_powiatowe, Access: 10.01.2019. 
5. Europejska Karta Samorzadu Terytorialnego (European Charter of Local Self-Government), Dz.U. 1994, Nr 124 poz. 607, Retrived: https://rm.coe.int/16807198a3, Access: 12.01.2019.

6. Jaska, E.,Werenowska, A. (2018) The Availability and Use of Media Information Sources in Rural Areas. Proceedings of the 2018 International Scientific Conference "Economic Science For Rural Development". No 47. Jelgava, LLU ESAF. pp.115.

7. Kantane, I., Sloka, B., Vilcina, A., Ozolina, I. (2012) Role of Communication for Development of Small and Medium Size Enterprises in the Regions of Latvia, Proceedings of the 2018 International Scientific Conference „Economic Science for Rural Development". Jelgava, LLU ESAF. p. 113.

8. Kielbasa, B., Kalinowski, S. (2018) Knowledge and Information in the Processes of Managing the Organization. Case Study. Conference Proceedings "Towards Productive, Sustainable and Resilient Global Agriculture and Food Systems", Ed. E. Horská, Z. Kapsdorferová, M. Marcela Hallová, Published by Wolters Kluwer ČR, a. s., pp. 815-829, DOI: 10.15414/isd2018.s3.08.

9. Killingsworth, C. (2009) Municipal Government Communications: The Case of Local Government Communications. The McMaster Journal of Communication. Vol. 6. Iss. 1. Article 5. pp. 59-79.

10. Komunikacja wewnetrzna (Intenal Communication), Raport GFMP 2016, Retrieved: https://gfmp.com.pl/wpcontent/uploads/GFMP-Komunikacja-wewnetrzna-Raport-2016.pdf, pp. 1-6, Access: 11.12.2018.

11. Kruzmetra, Z., Bite, B., Kronberga, G. (2018) Government-Citizen Communication in Rural Municipalities In Latvia. Proceedings of the 2018 International Scientific Conference „Economic Science for Rural Development". No 48. Jelgava, LLU ESAF. pp. 154-163.

12. Ksztaltowanie procesu komunikacji wewnetrznej w urzedzie (Shaping The Internal Communication Process in The Office), Retrived:

http://www.przyrow.pl/app/webroot/img/tiny_uploads/file/caf/Podr \%C4 \%99cznik.pdf, Access: 17.01.2019.

13. Marcysiak, T., Prus, P. (2017). Life strategies of rural inhabitants of unfixed economic function. Proceedings of the 26th International Scientific Conference Agrarian Perspectives XXVI "Competitiveness of European Agriculture and Food Sectors", Czech University of Life Sciences Prague, Faculty of Economics and Management. pp. 212-218.

14. Maruszak, P. (2014) Public relations zaczyna sie w domu - istota komunikacji wewnetrznej (Public Relations Starts at Home - the Essence of Internal Communication). Toruńskie Studia Bibliologiczne (Toruń Biblilogical Studies). No 1 (12). pp. 99-111. DOI: 10.12775/TSB.2014.007.

15. Mistre, Z., Zvaigzne, A. (2012) Assessment of Development Scenarios for The Regional Internal Communication and Information System of the Latvian Blood Donors Service. Proceedings of the 2012 International Conference Economic Science for Rural Development. No 28. Jelgava, LLU ESAF. pp. 91-98.

16. Nielsen, J.A., Salomonsen Houlberg, H. (2012) Why All This Communication? Explaining Strategic Communication in Danish Local Governments from an Institutional Perspective. Scandinavian Journal of Public Administration. No 16(1). pp. 69-89. ISSN 1402-8700, e-ISSN 2001-3310.

17. Ustawa z dnia 5 czerwca 1998 r. o samorzadzie powiatowym, Dz.U. z 2018 r., poz. 995 (the Act of June 5, 1998 about the poviat self-government, Dz.U. z 2018 r., poz. 995).

18. Ober, J. (2007) Informacja i komunikacja w zarzadzaniu (Information and Communication in Management). Politechnika Śląska. pp. 34-57.

19. Poznanska, A. (2012) Komunikacja medialna a sfera publiczna: szanse i zagrozenia (Media Communication and the Public Sphere: Opportunities and Threats). Karkonoska Państwowa Szkoła Wyższa. Jelenia Góra. pp. 116-121.

20. Prus, P., Drzazdzynska, K. (2017) Farmers' assessment of training services and the impact of agricultural advisory on selected developmental factors affecting farming. Proceedings of the 2017 International Conference „Economic Science For Rural Development”. No 44. Jelgava, LLU ESAF. pp. 338-344.

21. Satola, L. (2014) Instytucje społeczenstwa obywatelskiego na obszarach wiejskich a sprawnosc wykorzystania funduszy Unii Europejskiej (na przykładzie wojewodztwa malopolskiego) (Civil Society Institutions in Rural Areas and Their Efficiency in Absorbing the European Union Funds (on the Example of the Małopolska Province). Samorząd Terytorialny (Local self-government). No 5. pp. 24-35.

22. Smalec, A. (2015) Local Government Offices Communication with Respect To Residents Of New Concept Of Management. Proceedings of the MarkeLearn and TIIM Joint International Conference: Managing Intellectual Capital and Innovation for Sustainable and Inclusive Society. pp. 1335-1341.

23. Supernat, J. (2004) Administracja publiczna w swietle koncepcji New Public Management (Public Administration in the Light of the New Public Management Concept). In: "Jednostka, panstwo, administracja - nowy wymiar" (Unit, State, Administration - a New Dimension). (Ed.) E. Ura. Międzynarodowa Konferencja Naukowa Olszanica. Rzeszów. pp. 469-470.

24. Werenowska, A. (2014) Possibility of applying modern forms of communication of agritourism farms with environment groups. „Economic Science for Rural Development”. No 35. Jelgava, LLU ESAF. pp. 80. 